\title{
Law making by law breaking? A theory of parliamentary civil disobedience against international human rights courts ${ }^{1}$
}

Approximately as appears in The International Human Rights Judiciary and National Parliaments: Europe and Beyond, eds. M. Saul, A. Follesdal and G. Ulfstein, Cambridge University Press 2017: 329-352

Wie Schiffer sind wir, die ihr Schiff auf offener See umbauen müssen, ohne es jemals in einem Dock zerlegen und aus besten Bestandteilen neu errichten zu können.

[We are like sailors who have to rebuild their ship on the open sea, without ever being able to dismantle it in dry-dock and reconstruct it from the best components.]

(Neurath 1932, 92)

\section{Introduction: The Puzzle - law making by law breaking}

Recent cases of non-compliance with judgments of the European Court of Human Rights (ECtHR) raise several profound questions of legitimacy. Some states seem simply unwilling to defer to the ECtHR, putting their own legitimacy on the line. Other cases, such as the Hirst v. $U K$ case of prisoners' voting rights, seem to challenge the legitimacy of the Court or aspects of its practices. ${ }^{2}$ May some such non-compliance with international courts in fact be justifiable? The present chapter argues that some forms of parliamentary disobedience may be understood and assessed not only as protest and avoidance, but also as a constructive mode of correcting the law making of the ECtHR. Under some conditions, certain forms of domestic parliamentary disobedience should be considered as and accepted as an extreme form of multi-level law making.

A central normative challenge for international courts (ICs) is that they risk replacing the rule of law with the rule of lawyers. The IC must be sufficiently independent of the state parties to the disputes, and still remain sufficiently accountable. This design question arises not only when ICs adjudicate, but even more so when they embark on dynamic interpretations of international law. Such law making is even more necessary in areas of international law than in domestic law, since the negotiated treaties, 'general principles' and 'customary international law' are vague, often deliberately left indeterminate by the negotiating state

\footnotetext{
${ }^{1}$ This article was written under the auspices of ERC Advanced Grant 269841 MultiRights —on the Legitimacy of Multi-Level Human Rights Judiciary; and partly supported by the Research Council of Norway through its Centres of Excellence Funding Scheme, project number 223274 - PluriCourts The Legitimacy of the International Judiciary. The first version of this paper was presented 13 March 2015, at a MultiRights Workshop on 'The International Human Rights Judiciary and National Parliaments,' Oslo, 12-13 March 2015, directed by Matt Saul. I am grateful to Mitchell Robinson for discussions at an early stage - discussions which may yield yet another paper on this topic including policy implications. Thanks to Matt Saul and others as noted for helpful suggestions.

${ }^{2}$ Hirst v United Kingdom (No 2) Application No 74025/01, 6 October 2005.
} 
parties. This law making function further fuels the 'countermajoritarian' criticism against ICs' override of democratically accountable legislatures. To some extent such review might be defended as a self-imposed constraint states undertake to secure similar self-binding by other states, or to bolster their credibility among important constituencies - be it investors or their own citizens. But such arguments are strained when ICs engage in necessary but contested treaty interpretation, even when warranted by the object and purpose of the treaty. ${ }^{3}$ Surely there must be some limits to such interpretation: presumably some interpretations are mistaken. Theories of legitimacy typically hold that the point of having an authority is that it pre-empts the subjects' other reasons to act and thus prohibits the subjects from acting in every case on their own assessment. ${ }^{4}$ Yet the most convincing legitimacy theories only argue that such pre-emption goes up to a certain point: beyond some limits a particular IC may lack legitimate authority - and in some such cases, non-compliance may be justified. ${ }^{5}$

There must therefore be ways to check and guide ICs' interpretations if their authority is to be legitimate. The present multi-level legal system not only hinders such checks, but increases the need for them. The ICs' law making is both more necessary and less checked than their domestic counterparts'. No international legislator can correct ICs' interpretations by revising treaties with procedures reminiscent of how legal acts or constitutions are modified by domestic legislatures. Treaty changes are often far more cumbersome than domestic legislative or even constitutional changes. A 'conference of the parties' may allow for some changes without formal amendments, ${ }^{6}$ otherwise unanimity or at least consensus among most states is required for treaty change.

There are few procedures to challenge or correct ICs' interpretation of customary international law or general principles of international law. And the risks are high that a state will protest a particular interpretation largely because the interpretation is contrary to its interests. Such risks are especially high in international human rights law cases. They are typically disputes between an individual and a state, rather than state-state disputes. In the latter case states on either side of the dispute may support conflicting interpretations. In contrast, human rights ICs are likely to be urged by several states to prefer interpretations

\footnotetext{
${ }^{3}$ United Nations, Vienna Convention on the Law of Treaties, Vienna, 23 May 1969, in force 27 January 1980, 1155 UNTS 331.

${ }^{4}$ J. Raz, 'The Problem of Authority: Revisiting the Service Conception', Minnesota Law Review, 90 (2006), $1003-1044$.

${ }^{5}$ A. Applbaum, 'Legitimacy without the Duty to Obey', Philosophy and Public Affairs, 38 (2010), 215-239., 220.

${ }^{6}$ J. K. Cogan, 'Noncompliance and the International Rule of Law', Yale Journal of International Law, 31 (2006), 189-210., 197.
} 
which grant all of them broader discretion. Few states can be expected to pressure human rights ICs to interpret the treaties expansively. Thus states might not be suitable actors in a system of checks to ensure that ICs interpret in appropriate ways. Yet checks and balances should be developed in our multi-level legal order to alleviate these risks wrought by ICs' interpretation and law making.

\subsection{Varieties of non-compliance distinguished}

This article explores and defends one response to this challenge: domestic legislators may deliberately disobey an IC, the ECtHR in particular, in an ultimate effort to correct its interpretation or application of international law. Such non-compliance has received some academic attention, and must be distinguished from other forms. ${ }^{7}$

That domestic parliaments, executives or judiciaries sometimes choose to disobey decisions that go against them should come as no surprise, especially when cooperation is costly and sanctions are scarce. ${ }^{8}$ Yet states often defer to international law and to judgments of international courts (ICs) in general and to human rights courts in particular - but not always.

Some such noncompliance may simply be disobedience which cannot be justified. Often it may be difficult to determine whether there is noncompliance: national judges will consider the ECtHR's case law, but find ways to distinguish the case at hand and claim that they are nonetheless complying. ${ }^{9}$ Sometimes the noncompliance may be an extreme mode of protest to voice displeasure. ${ }^{10}$

Some noncompliance appears largely as claims to be exempt from a generally accepted rule - without any claim that the rule itself should change. ${ }^{11}$ Parliaments, governments or domestic judiciaries may all make such claims. Colm and Bates discuss the former cases as examples of 'democratic overrides', where a national parliament in an

\footnotetext{
${ }^{7}$ A. Buchanan, 'From Nuremburg to Kosovo: The Morality of Illegal International Legal Reform', Ethics 111 (2001), 673-705.

${ }^{8}$ G. Downs, et al., 'Is the Good News About Compliance Good News About Cooperation?', International Organization, 50 (1996), 379-406.

${ }^{9}$ G. Martinico, 'National Courts and Judicial Disobedience to the ECHR: A Comparative Overview', in Oddný Mjöll Arnardóttir \& Antoine Buyse (eds.), Shifting Centres of Gravity in Human Rights Protection: Rethinking Relations between the ECHR, EU, and National Legal Orders (London: Routledge, 2016), p. 79-100.

${ }^{10}$ F. G. E. Sundberg, 'The European Experience of Human Rights Proceedings: The Precedential Value of the European Court's Decisions', Akron Law Review, 20 (1987), 641, referred to by L. Helfer, 'Consensus, Coherence and the European Convention on Human Rights', Cornell International Law Journal, 133 (1993), 133-165, 134.

${ }^{11}$ Cogan, 'Noncomplianceæ', 208.
} 
exceptional case decides to not give effect to a judgment it disagrees with. ${ }^{12}$ Such exemptions do not amount to attempts to change international law toward a preferred alternative, but are rather claimed to be cases where the power of the ECtHR needs to be curtailed.

The second kind of case arises when domestic judges and scholars allow for judicial non-compliance. ${ }^{13}$ The 'Solange' judgments of the German Federal Constitutional Court may be taken to express this - not against a human rights IC but with regard to human rights, against the Court of Justice of the European Union. ${ }^{14}$ The German Constitutional Court also refused to comply with an ECtHR judgment due to concern for other affected parties than those involved in the case, with a justification the German Constitutional Court has repeated in later cases:

The Basic Law aims to integrate Germany into the legal community of peaceful and free states, but does not waive the sovereignty contained in the last instance in the German constitution. There is therefore no contradiction with the aim of commitment to international law if the legislature, exceptionally, does not comply with the law of international agreements, provided this is the only way in which a violation of fundamental principles of the constitution can be averted. ${ }^{15}$

In the UK Lord Manc has likewise not ruled out disobedience with rulings by the ECtHR, but he underscores that

It would then have to involve some truly fundamental principle of our law or some most egregious oversight or misunderstanding before it could be appropriate for this Court to contemplate an outright refusal to follow Strasbourg authority at the Grand Chamber level. ${ }^{16}$

Other cases of noncompliance of this kind are non-authorised humanitarian interventions, defended as normatively permissible exemptions. If the main argument on behalf of these law

\footnotetext{
${ }^{12}$ Colm, 'Xxx', in this volume; E. Bates, 'Democratic Override (or Rejection) and the Authority of the Strasbourg Court: The UK Parliament and Prisoner Voting', $\mathrm{p}$ xxx this volume]

${ }^{13}$ P. Mahoney, 'The Relationship between the Strasbourg Court and the National Courts', The Law Quarterly Review 130 (2014), 568-586.

${ }^{14}$ Bundesverfassungsgericht, 'Solange I: Internationale Handelsgesellschaft v. Einfuhr Und Vorratsstelle Für Getreide Und Futtermittel', BVerfGE 37, 271 (1974), , Bundesverfassungsgericht, 'Solange II: Wuensche Handelsgesellschaft' (1986), 2 BvR 197/83.

${ }^{15}$ Görgülü [Gorgulu], (German Federal Constitutional Court, 2 BvR 1481/04), para. 34-35; repeated Gauweiler v. Treaty of Lisbon, (German Federal Constitutional Court 30 June 20092 BvE 2/08).

${ }^{16}$ (R) Chester v. Secretary of State for Justice, (UK Supreme Court), cited in Mahoney, 'The relationship between the Strasbourg and court and the national courts',
} 
breakers is the necessity of violating existing international law — without proposing that the rules or their interpretation should change - this does not count as civil disobedience in the way proposed here. To illustrate, consider the NATO intervention in Kosovo. This was illegal under international law since the intervention lacked prior authorization by the UN Security Council. The Independent International Commission on Kosovo famously held that the intervention was still legitimate. ${ }^{17}$ Thomas Franck famously argued that it was still a morally mandatory act of 'international civil disobedience'. ${ }^{18}$ His usage of the term deviates from the one proposed here, insofar as NATO did not also express a preferred change in the rules regulating humanitarian intervention. In contrast, the same Commission laid out a proposal for a process to establish a new doctrine for humanitarian intervention. ${ }^{19}$ If later illegal humanitarian interventions refer to such proposals they may be acts of civil disobedience as defined here.

The noncompliance of interest here differs from those mentioned hitherto. What are we to make of noncompliance that aims not to exempt the state from the interpretation or judgment, but instead to change the IC's interpretation or law making? ${ }^{20}$ Some such acts of noncompliance may be understood as checks on the IC 'ex post' ${ }^{21}$ e.g. by finding their judgments ultra vires. Thus ICJ judge Fitzmaurice held that the binding effect of a UN resolution may be challenged by an individual state when the act's illegality is 'apparent on the face of the matter'. ${ }^{22}$

The concern here, however, is not the multi-level check of ICs by domestic courts, but rather by domestic parliaments. The relevant cases are then where the domestic parliament seriously considers non-compliance with a particular decision by a human rights IC. The justification is not only that this judgment violates the domestic constitution, but that the IC's interpretation of the treaty, or the treaty itself, should be modified. Parliament may then be seen as seeking to change the interpretation or application of the legal norms as an extraordinary 'dialogue' with the IC.

\footnotetext{
${ }^{17}$ The Independent International Commission on Kosovo, The Kosovo Report: Conflict, International Response, Lessons Learned (Oxford: Oxford University Press, 2000), p. 4.

${ }^{18}$ T. M. Franck, 'Lessons of Kosovo', American Journal of International Law, 93 (1999), 857-60; R. Dworkin, 'A New Philosophy for International Law', Philosophy and Public Affairs 41 (2013), 2-30.

${ }^{19}$ Kosovo, 'The Kosovo Report', p. 185-187.

${ }^{20}$ On the difference between noncompliance by domestic legislatures and domestic judiciaries in the case of the Inter-American Court of Human Rights, cf. A. Huneeus, 'Courts Resisting Courts: Lessons from the InterAmerican Court's Struggle to Enforce Human Rights', Cornell International Law Journal, 44 (2011), $493-533$. ${ }^{21}$ L. Helfer, 'Why States Create International Tribunals: A Theory of Constrained Independence', in Stefan Voigt, et al. (ed.), International Conflict Resolution (Tubingen: Mohr Siebeck, 2006), p. 253-280.

${ }^{22}$ UN Expenses (ICJ), separate opinion p. 203, discussed by F. Francioni, 'Multilateralism À La Carte: The Limits to Unilateral Withholdings of Assessed Contributions to the UN Budget', European Journal of International Law, 11 (2000), 43-59.
} 
The function and objective of such acts render them subject to other standards of assessment than other forms of non-compliance. The particular objective is a change of ICs' interpretation of international law, pursued by illegal means under international law, and undertaken in full publicity. The concerns here are changes to treaty norms, leaving aside attempts to change customary international law e.g. as a persistent objector. ${ }^{23}$

The present reflections seek to specify the definition and conditions for justifiable noncompliance by such persistent objectors - parliaments in particular; and the European Court of Human Rights (ECtHR) in particular. These actors and such human rights ICs have particular strengths and pose particular challenges. Parliaments are often suited to such attempts at changing an IC's interpretation: their law making may enjoy legitimacy by being democratically accountable, and they engage in extensive public deliberation and justification. On the other hand, illegal protests against international and regional human rights courts appear especially threatening to the legitimacy of these courts. A main function of these ICs is to allow states to increase their credibility when they claim that they are committed to human rights. Non-compliance may question that state's commitment, and may also damage the credibility of the ECtHR as a commitment device for other states - especially if the human rights credentials of the protesting state is otherwise not in doubt.

\subsection{The nature of injustice to be corrected}

Which sorts of corrections may parliaments be urging through non-compliance? The ECtHR's judgments will either find a violation by the state, or find no violation. If a parliament thus believes that the Court makes a mistake in a case against its own state, it is likely to either concern the interpretation of a Convention right, or the Court's 'balancing' of conflicting Convention rights, or the extent of discretion the Court grants the state in determining whether a violation has occurred. Examples might be if the Court overrules a state's banning of hijab or minarets, or a state's blanket denial of prisoners' right to vote; or the state's balance between freedom of speech and respect for privacy e.g. concerning hate speech. Other pertinent cases may arise if a state believes that the Court fallaciously permits another state to violate a Convention right. In some such cases one might imagine that a parliament decides to disobey some other judgment of the Court in order to bring attention to that other case, though such signalling seems exceptionally difficult in the international arena.

\footnotetext{
${ }^{23}$ R. Goodin, 'Toward an International Rule of Law: Distinguishing International Law-Breakers from Would-Be Law-Makers', Journal of Ethics, 9 (2005), 225-246; P. Dumberry, 'Incoherent and Ineffective: The Concept of Persistent Objector Revisited', International and Comparative Law Quarterly, 59 (2010), 779-80.
} 
I submit that we can bring some light on the issues by understanding these acts as a form of civil disobedience. We can of course not merely transpose sound theories of civil disobedience from domestic settings onto these matters of international law. ${ }^{24}$ The nature of the international legal system affects these standards and criteria in ways that should affect how parliaments should select and present their noncompliance, and how other bodies should respond to such non-compliance. These differences notwithstanding, John Rawls' theory of civil disobedience is particularly helpful. ${ }^{25}$

\subsubsection{Why John Rawls' theory of civil disobedience?}

John Rawls understands civil disobedience as an exceptional mechanism to correct unjust laws. This understanding is particularly relevant for our concerns, where many treaties have few practicable procedures for treaty changes, and where judges of the ICs exercise very broad discretion in interpretations. The following account draws on John Rawls' theory of civil disobedience, laid out in some sections of his magisterial A Theory of Justice. ${ }^{26}$ This is one of the most influential accounts of civil disobedience - critics notwithstanding. ${ }^{27}$

Rawls' account is highly relevant for our concerns because it is developed as part of a broader theory of the justice and legitimacy of state authority - thus closer to our starting point than theories based on premises of anarchism. It recognizes the tension between respecting and reforming law through disobedience - a tension which arguably is even more visible and risky in the case of international law. ${ }^{28}$ Rawls' broad framework also helps show that discussions of the legitimacy of international law, and the possible justifiability of violations of international law, are not only murky attempts an manipulation. ${ }^{29}$ One important contribution in this regard is the distinction this theory draws between defining criteria of civil disobedience and justificatory criteria. The theory thus recognizes that there may be acts of

\footnotetext{
${ }^{24}$ Goodin, 2005, N. Kokaz, 'Theorizing International Fairness', Metaphilosophy 36 (2005), 68-92; G. Neubauer, 'State Civil Disobedience: Morally Justified Violations of International Law Considered as Civil Disobedience', TranState Working paper no 86 (2009), 5.

${ }^{25}$ At the same time, this approach allows us to test the scope conditions and implications of domestic theories of civil disobedience - John Rawls' influential theory in particular. J. Rawls, A Theory of Justice (Cambridge, Mass.: Harvard University Press, 1971), p. 363; A. Follesdal, 'John Rawls' Theory of Civil Disobedience' Unpublished Magister Artium Thesis, University of Oslo (1982),p.

${ }^{26}$ J. Rawls, A Theory of Justice (Cambridge, Mass.: Harvard University Press, 1971), pp $363 .$.

${ }^{27}$ D. Lyons, 'Political Responsibility and the Resistance to Civil Government', Philosophic Exchange (1995), 525; A. J. Simmons, 'Disobedience and Its Objects', Boston University Law Review, 90 (2010), 1805-31..

${ }^{28}$ J. Tasioulas, 'The Legitimacy of International Law', in Samantha Besson \& John Tasioulas (eds.), The Philosophy of International Law (Oxford: Oxford University Press, 2010), p. 97-116.

${ }^{29}$ M. Koskenniemi, 'Legitimacy, Rights and Ideology, Notes Towards a Critique of the New Moral Internationalism', Associations: Journal for Legal and Social Theory, 7 (2003), 349-373.
} 
civil disobedience that are normatively unjustified. ${ }^{30}$ The theory of civil disobedience furthermore considers the justifiability of civil disobedience under circumstances of not fully just legal orders, also highly relevant for our purposes. Furthermore, Rawls' theory places great weight on the public justification required for such illegal acts - a requirement which makes parliaments' role particularly salient. Finally, his theory recognizes the risk that illegal acts may unravel respect for the rule of law in general. This risk is arguably higher for international law than within stable states that benefit from general compliance.

The voluntary nature of treaty obligations may appear to be one important difference to theories of civil disobedience. The latter is developed for issues arising for citizens within a domestic legal order - a legal order which citizens for practical purposes usually cannot avoid. Citizens also bear greater responsibility for domestic injustices insofar as their state wields its power 'in the citizens' name'. In contrast, states can withdraw from a treaty and thus end their international legal obligations, and reduce their moral complicity in the injustice. ${ }^{31} \mathrm{I}$ submit that the difference is not as striking as might be thought, for three reasons. Firstly, states are not only subject to treaty obligations, but also non-consent-based customary international law and principles of international law. Secondly, some treaties, including the European Convention on Human Rights (ECHR), are in practice very costly for states to exit. A state that decides to exit from the ECHR would not be eligible for membership in the European Union - an option of great value to many European states. Thirdly, civil disobedience may be an attractive option for states - and ICs - as it may be a way to keep a state from withdrawing from a treaty and possibly seek to create a competing international organization. ${ }^{32}$ Such illegal acts might therefore arguably be less costly for the state and for the ICs - but at the risk of undermining respect for international law as a whole. ${ }^{33}$ This is not to deny that exit may also be an effective instrument to urge change. Thus the UK and the US left UNESCO in the mid-1980s, the UK re-joining 1998, the US in 2003. These processes arguably promoted reforms of UNESCO.

The various actors faced with such scenarios of noncompliance need to respond in ways that build their legitimacy and the international rule of law in the longer run. I shall suggest that there are several lessons from Rawls' theory of civil disobedience.

Section 2 of this article lays out Rawls' theory of civil disobedience: scope conditions,

\footnotetext{
${ }^{30}$ Cogan, 'Noncompliance', 208.

${ }^{31}$ I am grateful to Colin Muray for urging this clarification.

32 J. Morse and R. Keohane, 'Contested multilateralism', The Review of International Organizations 9 (2014), 385-412.

33 cf Bates, xxx.
} 
defining characteristics and justificatory conditions. Section 3 seeks to identify which acts of noncompliance to ICs may count as equivalent ultimate corrective devices; section 4 explores the conditions for when such acts are justified. Section 5 illustrates these accounts with two partly hypothetical cases: that of Hirst and Animal Defenders, both against the United Kingdom. Section 6 considers how other actors should respond to such acts.

\section{Rawls' theory of civil disobedience}

John Rawls' theory of civil disobedience explores an interpretation of the role or 'social function' of civil disobedience as an 'ultimate stabilizing device. ${ }^{34}$ This may be a helpful guide in the debate, both as regards how to define this set of actions, and to determine under which conditions they may be justified.

Wilful noncompliance with the law can be normatively justified for a variety of reasons, not least in less just states. One interesting kind of case is when the protester seeks to appeal to the shared sense of justice of the community - in particular the authorities. The protester seeks to argue that whilst the authorities are generally normatively justified to rule, this particular judgment or policy is so far beyond the limits laid out by that sense of justice that disobedience is warranted. The aim is to correct the flaws of a generally well-functioning legal system - whilst minimizing the risk of its unravelling.

\subsection{Scope conditions}

Rawls is concerned with protests in a nearly just legal and political order. In sufficiently unjust societies there may be no moral requirement to protest in such a 'civilized' way. The society at large including the authorities must have a shared 'sense of justice' in the sense of some commitment to substantive normative principles of justice. And the system must be robust enough to allow actors within the state - such as legislatures, courts or the executive to seek to correct the flaws of the legal system by specific acts of noncompliance without putting the system as a whole at a risk.

On the basis of this account of civil disobedience, Rawls lays out six defining characteristics and four conditions for such acts to be justified:

D1. The act is contrary to the law

D2. The act is conscientious and political — The target is not only something that one's own morality rejects, but something which violates what is taken to be broadly shared principles of

\footnotetext{
${ }^{34}$ Rawls, 'A Theory of Justice', p. 383.
} 
a 'public justification' of the domestic basic structure of society.

D3. The act is meant to bring about change — not 'merely' an act of conscientious objection seeking exemption, but rather to change the decision.

D4. The act is public - to draw attention to the alleged injustice and promote change.

D5. The act is non-violent. The reason for this requirement is to express and publicly confirm the protester's ultimate commitments to respect for principles of justice.

D6. The agent accepts the consequences - i.e. punishment if given - in order to both make the case public and show general respect for law and the rule of law. ${ }^{35}$

\subsection{When justified?}

Acts of civil disobedience as defined are not always justified. Rawls' account lays out four conditions:

J1. The injustice protested must be a clear violation of the appropriate normative principles. In the domestic setting of concern for Rawls, he holds that serious violations of the principles of justice he defends would have to occur.

J2. Normal appeals should have been made and have failed - at least if they are not obviously going to be ineffectual.

J3. The total amount of civil disobedience in the society must be kept within limits, to prevent unravelling of the basic structure as a whole

J4. Injury of the innocent must be avoided. This is one way to express continued commitment to the central values justifying the legal order.

Note that it is not a requirement on this account that the civilly disobedient act must be without self-interested motives. Thus women, or minorities, may justifiably protest patriarchal regulations or laws that discriminate against minorities by civil disobedience even though the protesters themselves stand to gain by the changes. Nor is it a requirement of just acts of civil disobedience on this account that they actually succeed in promoting more just rules or institutions.

\section{A theory of civil disobedience against international courts}

What would be required for a violation of international law to be regarded as normatively legitimate under certain conditions reminiscent of those familiar from such theories of

\footnotetext{
${ }^{35}$ M. L. King, 'Letter from a Birmingham Jail', AJ Muste Memorial Institute Essay Series 21 (1963). For a dissenting account, cf. F. A. Boyle, Protesting Power: War, Resistance and Law (Lanham: Rowman, 2008), p. 41.
} 
domestic civil disobedience? If we follow Rawls' account, the defining characteristics should be specified by an interpretation of such acts as ultimate corrective devices to international law or of international courts. This may fit with, and expand on, Larry Helfer's and Anne Marie Slaughter's claim that

noncompliance, standing alone, may not be understood as a sanction by jurists or by observers. It may, however, be viewed in this way when used to augment challenges to a tribunal's legitimacy. As a practical matter, the efficacy of noncompliance as a judicial control mechanism is likely to vary with the state's success in linking these two strategies. Where the material or reputation costs of noncompliance are well established or fairly automatic, it will be more difficult to pin the fault on the tribunal rather than on the noncomplying state. Conversely, a noisy act of noncompliance by a powerful state that occurs early in a tribunal's life may devastate its legitimacy. ${ }^{36}$

Several premises and ranges of alternatives differ from the domestic setting and scope conditions, but it would appear that several alleged differences are not decisive. To clarify, consider some objections.

Some may challenge the relevance of a theory of civil disobedience to international law. Critics may hold that to speak of civil disobedience may falsely insinuate that the present global order is nearly just. Recall that civil disobedience is here defended as a corrective device for one of few flaws in a nearly just constitutional order system which otherwise merits obedience. Critics may argue that this is a flawed description of the current status of international law. The international legal system may be so unjust that it does not carry much moral authority. The relevant theory is not one of civil disobedience, but of just revolution.

In response, I firstly submit that civil disobedience may also be seen as a corrective device for less just legal orders - though its impact may be less insofar as any shared conception of global justice is weak or non-existent. And the risk of jettisoning the benefits of the current international legal system may be such that the parallels to civil disobedience are still relevant. Indeed, the Universal Declaration on Human Rights may be called on in support of looking for civil disobedience: its Preamble holds that 'Whereas it is essential, if man [sic] is not to be compelled to have recourse, as a last resort, to rebellion against tyranny and oppression, that human rights should be protected by the rule of law.' Civil disobedience is from this perspective a valuable alternative to rebellion. A further response to this objection is

\footnotetext{
${ }^{36}$ L.Helfer and Anne-Marie Slaughter, 'Why states create international tribunals: A response to professors Posner and Yoo', California Law Review 93 (2015), 54.
} 
that the European Convention on Human Rights is arguably among the more legitimate parts of international law, aimed to bolster domestic human rights protection within the member states of the Council of Europe. Yet this treaty and its interpretation still merit improvements, hence possibly the need for civil disobedience.

A second concern is the lack of global agreement about standards of global justice. There is apparently much less agreement among individuals globally about what global justice requires, than about what domestic justice requires among citizens of a fairly well ordered, just domestic legal order. In response, note that international human rights law is arguably less subject to such criticism. Several international human rights treaties are accepted by a wide range of states, and this arguably holds especially for the European Convention on Human Rights interpreted by the ECtHR.

A third reason to hesitate is that the risk of destabilization is higher for international law. Compliance with international law is lower than compliance with domestic law in wellfunctioning, nearly just domestic legal orders. The precarious structure of international regimes is more likely to unravel by noncompliance. This is indeed a plausible objection which appears relevant when assessing when - if at all - such noncompliance is permitted. Note, however, that compliance with the ECHR varies greatly. In 2011 the Nordic states and the UK were responsible for only1.5\% of the violations found by the ECtHR. This is much less than the per capita would suggest, since these states include $10.7 \%$ of the population of the Council of Europe member states. ${ }^{37}$

A further difference concerns the potential audiences of such international civil disobedience in the absence of a division of power familiar from domestic constitutional orders, so the target of such disobedience is less clear. On the other hand, since there are few other mechanisms to correct ICs' mistakes, civil disobedience may indeed appear to be a justifiable 'last resort' with some frequency. Parliamentary protest in the form of noncompliance may target the member state governments or parliaments responsible for agreeing to treaty protocols. Several treaties allow 'conferences of the parties' which can agree to modifications without requiring formal amendments. ${ }^{38}$ And the judges of the ICs are another

\footnotetext{
${ }^{37}$ In 2011 the ECtHR made a total of 1157 judgments finding violations in 987 of them; of which only 15 concerned Denmark, Finland, Iceland, Norway, Sweden and the United Kingdom (European Court of Human Rights, 'Statistics 1/131/3 2012' (2012), p. 1213). In 2011 these five states had 88 million persons, of almost 819 million living in the Council of Europe states (European Court of Human Rights, Analysis of Statistics 2011 $<$ http://www.echr.coe.int/NR/rdonlyres/11CE0BB3-9386-48DC-B012AB2C046FEC7C/0/STATS_EN_2011.PDF >, accessed on June 15, 2016)

${ }^{38}$ Cogan, 'Noncompliance', 197; reference to R. Churchill \& G. Ulfstein, 'Autonomous Institutional Arrangements in Multilateral Environmental Agreement', American Journal of International Law, 94 (2000), 623659 .
} 
important audience, to urge them to revise their interpretation. Indeed, they may be the most likely actor to convince to change treaty interpretation. In the ECHR setting, another important audience for parliamentary noncompliance may be the Committee of Ministers which oversees states' implementation of the judgments of the ECtHR. This Committee may heed the appeal when deciding whether the state has taken appropriate general or individual measures.

A final challenge to applying the framework of civil disobedience to international law is that the intention of law making will be difficult to convey with credibility. A parliament will have more difficulty in convincing other actors of their intention since there is a high risk that noncompliance will be misinterpreted as plain disobedience:

Given the frequency with which governments are believed to shirk compliance with international as compared to domestic law, noncompliance, standing alone, may not be understood as a sanction by jurists or by observers. It may, however, be viewed in this way when used to augment challenges to a tribunal's legitimacy. ... As a practical matter, the efficacy of noncompliance as a judicial control mechanism is likely to vary with the state's success in linking these two strategies. ${ }^{39}$

One implication may be that states with a stable record of compliance with international law are more likely candidates to credibly commit an act of civil disobedience. Another implication is that a credible public justification for the non-compliance is crucial. A parliamentary debate may provide exactly this.

We now consider the various defining characteristics as they apply to international noncompliance.

\section{D1 The act is contrary to the law}

The acts of concern are those where a state admits to act technically in violation of international law. This definition thus excludes several high profiles of noncompliance, for instance if a domestic court claims that a regional or international court has decided a case ultra vires.

\section{D2 The act is conscientious and 'political'}

The relevant noncompliance is thus not one where the main concern is 'only' to seek an exemption. Note that the parliament may have mixed motives, but one claim must be that the

\footnotetext{
${ }^{39} \mathrm{Helfer}$ and Slaughter, 'Why states create international tribunals', 54 .
} 
judgment or the norm is normatively unacceptable..$^{40}$

\section{D3 The act is meant to bring about change in the international norm}

One objective of the noncompliance must be to have the legal norm or interpretation changed. Evidence for such objectives may be found in the public nature of the noncompliance, and the reasons given in the parliamentary debates. ${ }^{41}$

\section{D4 The act is publicly acknowledged as violating the international obligations of the} state

The parliament must admit that it is in fact not complying with its international obligations. It should be clear that parliament is not only preparing a legal appeal, or trying to evade or postpone compliance. ${ }^{42}$

\section{D5 The act signals commitment to the underlying values, e.g. by being non-violent}

The noncompliance must be limited and consistent with the central norms which the ECtHR is thought to violate in its interpretation or judgment. The noncompliant parliament presumably agrees to these, including a commitment to treat individuals with respect on a footing of equality. Respect for some such constraints helps distinguish such acts from ordinary illegal actions. How might this requirement apply to relevant cases of illegal humanitarian intervention? Presumably, such acts must take extraordinary care to avoid collateral casualties and only resort to violence under strict conditions of proportionality.

\section{D6 The agent accepts the consequences}

In the international case, the state must accept the remedies imposed by the ECtHR. ${ }^{43}$ However, the civilly disobedient objectives might render the Committee of Ministers more lenient in accepting the state's efforts.

\section{Which such cases of international civil disobedience would be justified?}

To fix ideas, consider some possible, partly hypothetical candidate acts of non-compliance with the ECtHR: If the Court were to strike down the Swiss Constitution's prohibition against

\footnotetext{
${ }^{40}$ Gerald Neubauer, 'State civil disobedience: morally justified violations of international law considered as civil disobedience', TranState Working paper no 86 (2009); Francesco Francioni, Multilateralism à la Carte: The Limits to Unilateral Withholdings of Assessed Contributions to the UN Budget, European Journal of International Law 11 (2000), 43-59.

${ }^{41}$ Francioni, 'Multilateralism à la carte', 58.

${ }^{42}$ Robert Goodin, 'Toward an international rule of law: distinguishing international law-breakers from would-be law-makers', Journal of Ethics 9 (2005), 233. Thanks to Alice Donald for pushing this point.

${ }^{43}$ Ibid, 234.
} 
minarets which was the outcome of a popular referendum, ${ }^{44}$ or if the UK decides to maintain its blanket ban on prisoners' voting. What would be required for such illegal actions to be normatively justifiable acts of international civil disobedience according to this theory? ${ }^{45}$

As a backdrop, consider thought-provoking arguments that denounce any noncompliance with international law. Samantha Besson has rejected attempts at revising international law by illegal means:

Those authors' argument is that illegal revisions of international law are justified if they can make international law more legitimate. That idea does not pay sufficient heed, however, to the value of legality of international law, and hence to the normative requirements this value imposes on its law-making processes. These normative requirements inherent in the very legality of international law - together or possibly by contrast to those relative to its procedural or substantive legitimacy - make it counterproductive to hope for the illegal making of international law whatever the urgency of the matter. In the long run, and despite the occurrence of such forms of illegal law-making in current circumstances of international law, international law's legality will be able to consolidate itself only if its law-making processes are organized so as to reflect the very values inherent in the international rule of law. ${ }^{46}$

In response, I submit that this overstates the case against international civil disobedience. It may be true that in the long run there should be better law-making processes, thus reducing the need for such illegal corrective attempts. However, given that many argue the need for such illegal acts at the domestic level even for quite well-functioning democracies, it seems unduly optimistic to believe that a better international legislative procedure will ever fully avoid such grave injustices which warrant civil disobedience. Moreover, it appears unduly strict to claim that any illegal act challenges the legitimacy of any piece of international legislation. Until such better legislative processes are in place it seems necessary to allow international civil disobedience as an unfortunate second best.

We then turn to consider the criteria necessary for such acts to be justified.

\section{J1 The injustice protested must be a clear violation of the appropriate normative}

\footnotetext{
${ }^{44}$ Constitution of Switzerland Art 72(3. Previouslysuch cases have bene dismissed on the merits, cf Ouardiri v. Switzerland and Ligue des Musulmans de Suisse and Others v. Switzerland; http://hudoc.echr.coe.int/eng-press Doc Number: 887994.

${ }^{45}$ For an alternative, cf. Cogan, 'Noncompliance', 208.

${ }^{46}$ S. Besson, 'Sovereignty, International Law and Democracy', European Journal of International Law, 22 (2011), 373-387.
} 


\section{principles}

In the domestic setting, Rawls hold that the principles of justice as fairness apply.

For international law, the case may be more difficult to determine due to extensive disagreement concerning such normative principles. Koskenniemi's worry might seem appropriate, that there is no system of shared values internationally. ${ }^{47}$ However, the problem is not a general divergence of moral views generally. Thus Dworkin's concern is overdrawn:

The proposition that a sense of moral duty can justify violations of international law threatens to strangle the child. ${ }^{48}$

The civilly disobedient actors are not only reporting moral unease about a particular case. Instead they hold that a particular interpretation or norm violates principles of global justice and that the interpretation of the norm, or the norm itself should be changed. The claim is thus that there are better norms or patterns of judgments which avoid the problem without creating new ones. Thus individual acts of illegal humanitarian interventions cannot be defended on this model unless they also provide a better set of criteria for when such interventions should be permitted. This is of course not to argue that such interventions may never be justified, but rather that their defence may be different.

Also note that this requirement does not exclude noncompliance in cases which also promote the interests of the state, however defined. In contrast, Francioni's account appears to deem such acts unjustified by his 'Principle of integrity':

the Member State asserting a right to withhold does so in the genuine belief that the challenged decision constitutes a breach of the law and does not act in the pursuit of outcomes that are extraneous or ulterior to the breach or to the situation that has resulted from the breach. In this sense, subjective integrity largely coincides with good faith. $^{49}$

\section{J2 Normal appeals should have been made and have failed - at least if they are not obviously ineffectual}

In the cases of concern here legal efforts to change the perceived unjust international norms or rulings must have been exhausted or appear obviously ineffective. Thus the judgment should have been appealed, and attempts at securing a protocol to change the

\footnotetext{
${ }^{47}$ Koskenniemi, 'Legitimacy', p. 361-2.

${ }^{48}$ Dworkin, 'International law', 201323.

${ }^{49}$ Francioni, 'Multilateralism', 2000, 54.
} 
treaty or its interpretation should have been considered. ${ }^{50}$ Other forms of judicial and institutional dialogue should also have been considered and tried, if deemed at all effective. Thus the domestic parliament should have expressed its concerns, for instance when appealing the decision. ${ }^{51}$ Attempts at calling a conference of the parties should have been considered.

The 'dialogue' by the parliament might be highly critical of the ECtHR, including denunciation of this strand of the ICs judgments,

questioning the tribunal's reasoning, identifying errors it has committed, or highlighting its abuses of authority. That governments attach importance to such 'delegitimizing' strategies is suggested by the pains they take to denounce objectionable decisions even when they are purely hortatory. ${ }^{52}$

\section{J3 The total amount of civil disobedience in the society must be kept within limits, to prevent unravelling of the basic structure as a whole}

An act of international civil disobedience is justifiable only if it does not increase the risk of destabilizing a reasonably legitimate international legal order. This is a central worry due to the more precarious nature of international law.

Thus Dworkin warns that 'International law is fragile, still nascent and in critical condition."53 So scholars are concerned that

any breach of an international obligation can undermine not only the authority of the primary rule breached but also the authority and integrity of the international legal system itself because it undermines the assumption that states must comply with international law. ${ }^{54}$

A central risk is that a justifiable act of noncompliance will radiate so that other states will feel less constrained. ${ }^{55}$ Thus a weighty objection against illegal humanitarian intervention is Iraq. Any doctrine that would allow powerful nations to justify aggressive war as a protection of basic human rights boils with the danger of abuse.... permission to invade without Security Council authorization would prove massively divisive rather than a

\footnotetext{
${ }^{50}$ Cogan, 'Noncompliance', 2006, 196; Neubauer, 'State Civil disobedience' 2009, 19.

${ }^{51}$ Cf. Krommendijk, xxx fn 62.

${ }^{52}$ Helfer and Slaughter, 'Why States create', 54.

${ }^{53}$ Dworkin, 'International law' (2013) ,23.

${ }^{54}$ Cogan, 'Noncompliance', 2006, 204.

55 Thanks to Ed Bates for putting the issue thus.
} 
principle around which further consensus and salience might develop. ${ }^{56}$

This is an important consideration. However, it should not be overdrawn. Other forms of non-compliance foster less grave risks, and there are ways to reduce the risk even further. Indeed, an appropriate distinction has to be maintained between the legitimacy of international law and its stabilizing function. Again, it may well be argued that stability is in large part itself a function of legitimacy, and that the civilly disobedient protests of states are a vital resource for increasing the legitimacy of international law through publicizing injustices and facilitating legal reform. ${ }^{57}$

One implication is that justified international civil disobedience must be publicly justified with great care, to ensure broad understanding of the complaint and the proposed improvement.

Another implication is that such acts of civil disobedience are less likely to be justified early in an IC's life, when it is still building its legitimacy. Early non-compliance, even if otherwise justified, then runs a greater risk of damaging the IC.

\section{J4 Injury of the innocent must be avoided}

This criterion seems to hold without significant changes also for the international cases considered here.

Note that these conditions do not limit permissible civil disobedience to generally compliant states, or ones with a high quality of democracy, however measured. The credibility of a state which is a notorious non-complier may be questioned if the parliament engages in yet another violation of an ECtHR judgment but this time claims it is for lawmaking purposes. However, such questionable credibility is not itself decisive. What does matter is mainly the quality of the arguments and the deliberation in the particular case.

\section{Two Cases}

Consider now some partly hypothetical cases of noncompliance with the ECtHR's judgments. To help focus on the pertinent aspects, the cases involve the United Kingdom, which generally complies with the Court's rulings.

\footnotetext{
${ }^{56}$ Dworkin, 'New Philosophy', 25.

${ }^{57}$ M. Allen, 'Civil Disobedience, International', in Encyclopedia of Global Justice (Amsterdam: Springer, 2011), p. 133135.
} 


\subsection{Hirst - prisoners' voting}

Let us assume that the UK does not change its position on the Hirst case concerning the blanket ban on prisoners' voting. ${ }^{58}$ What would be required for this to count as a case of international civil disobedience by a national parliament? ${ }^{59}$ The fact that parliamentarians have mixed motives, using the case to take a stand against Europeanization of domestic legislation, does not prevent the case from qualifying. However, several of the defining characteristics are missing. The objective of the present noncompliance does not appear to be a revision of the ECHR norms, but instead an insistence that the UK should be exempt from the requirements in this particular case. Moreover, the appeals to national sovereignty seem insufficiently developed to provide a public justification for any specific change. However, the UK government did present arguments for why the Court should grant a margin of appreciation in this case. And the government also sought to argue its case in Scoppola No $3 .{ }^{60}$

If these weaknesses were alleviated, would the Hirst case of non-compliance be justified according to this account? The UK government has indeed pursued legal means to a great extent. These include calling the Brighton meeting which led to Protocol 15, aimed at ensuring a greater scope of a margin of appreciation for member states. However, other justificatory conditions require close scrutiny. In particular, claims that the ECtHR commits an injustice seem insufficiently supported.

A central point of the Court's decision is that the lack of good faith reasoning by Parliament removes claims by the UK to benefit from a margin of appreciation - a margin which the Court holds is wide in such cases:

[T] here is no evidence that Parliament has ever sought to weigh the competing interests or to assess the proportionality of a blanket ban on the right of a convicted prisoner to vote....it cannot be said that there was any substantive debate by members of the legislature on the continued justification in light of modern-day penal policy and of current human rights standards for maintaining such a general restriction on the right of prisoners to vote. ${ }^{61}$

However, as Bates shows in his discussion of this case in this volume, ${ }^{62}$ even though

\footnotetext{
${ }^{58}$ Hirst - cf footnote 2.

${ }^{59}$ For our purposes I leave aside that a special Joint Committee of the UK Parliament agreed in 2013 that there were sound reasons to change the law (http://www.publications.parliament.uk/pa/jt201314/jtselect/jtdraftvoting/103/103.pdf).

${ }^{60}$ For a presentation of these attempts, cf. Bates, in ed., pp. xxx,

${ }^{61}$ Hirst para 79.

${ }^{62}$ Ref to Bates, $\mathrm{xxx}$
} 
Parliament might not have done such a proportionality test, the UK government did argue that the voting ban was not indiscriminate - both in Hirst No. 2 and in its intervention in Scoppola v. Italy No $3 .^{63}$

A second, related problem concerns the risk that this non-compliance 'radiates' to other states. This risk is reduced insofar as the arguments are specified clearly. However, the lack of careful public arguments has facilitated other states' use of the Hirst case to justify their own non-compliance - on issues arguably less justified. Thus Russia has passed a bill enabling the Russian Constitutional Court to declare rulings of international bodies 'impossible to implement,' apparently with references to UK wariness of implementing ECtHR decisions. ${ }^{64}$

\subsection{Animal Defenders}

A second case which provides an illuminating contrast is the Animal Defenders case, also against the UK. ${ }^{65}$ Here the Grand Chamber in a 9 to 8 judgment did not overturn the domestic court's decision, that an NGO suffered no violation of its freedom of expression though denied advertising on TV and radio. In this case the UK could show that their parliament had undertaken a careful review and balancing of the relevant rights, and they argued that a lack of European consensus should lead the Court to grant the UK a margin of appreciation. Consider, hypothetically: if the Court had overturned the domestic decision, what would be required for non-compliance by the UK to count as civil disobedience - and possibly be justified?

In this case, parliament and other domestic authorities have paid careful attention to the relevant rights and case law, and referred to the need to regulate political advertising to promote democratic principles. The deliberations had underscored the need to provide political parties with free broadcasts, etc. These public arguments would indicate that such a hypothetical would indeed qualify as civil disobedience; particularly since the UK has arguably exhausted legal alternatives by seeking to change the Court's practice through the Brighton process. The careful arguments would also tend to minimize the risk that the disobedience would radiate unduly.

\footnotetext{
${ }^{63}$ Scoppola v. Italy, (Appl. No. 126/05), Judgment (Grand Chamber), 22 May 2012.

${ }^{64}$ (http://www.huffingtonpost.co.uk/2016/02/24/human-rights-act-abolition-putin-amnesty_n_9300252.html).

65 Animal Defenders International v. United Kingdom, Application no. 48876/08, 22 April 2013.
} 


\section{How should courts and other central actors respond to acts of international civil disobedience committed by a domestic parliament?}

What should the IC do when confronted with such cases of international civil disobedience? Such policy recommendations may have to hold regardless of whether the act is justified or not, since this is likely to be contested. Rawls suggests that in the domestic setting, courts may find that the act was an unjustified act of civil disobedience, and acknowledge the good intentions by imposing milder punishments. What is an IC such as the ECtHR to do once the Grand Chamber has issued its judgment, and the state disobeys? In the particular case it hardly seems plausible that the IC should reconsider the case - though it might be tempting e.g. to grant such a protesting state a margin of appreciation. Note that this deflecting strategy is somewhat different from an IC avoiding head-on conflicts with powerful states simply to reduce the risk of non-compliance. ${ }^{66}$ In the longer run, the Court should seriously consider a change in its interpretation, possibly drawing on the arguments presented by the protesting state.

Other actors are more free to express support or denouncement. In particular, other states and their bodies might chose to neither condemn nor otherwise sanction the illegal act. ${ }^{67}$ For instance, the Parliamentary Assembly may vote for an expression in favour of the protesting state's interpretation of the ECHR ${ }^{68}$ The Committee of Ministers may similarly support the state and be charitable in accepting its reparations. On the other hand, the discussions by the Parliamentary Assembly or the Committee of Ministers may well conclude that the noncompliant state is in the wrong, and instead giving public support to the contested doctrine instead of its overturn.

\section{Conclusions}

These reflections give rise to some tentative conclusions that go beyond the justifiability of noncompliance with judgments of the ECtHR.

I submit that the brief account above illustrates that it is possible to discuss the legitimacy of acts which are illegal under international law, without falling into the quagmires of subjectivism feared by Koskenniemi and others.

The discussion has also granted that there are risks of a slippery slope of noncompliance and abuse of discretion. However, these are not always overriding

\footnotetext{
${ }^{66} \mathrm{~K}$. Alter, 'Delegating to International Courts: Self-Binding vs. Other-Binding Delegation', Law and contemporary problems, 71 (2008), 3776

${ }^{67}$ Cogan, 'Noncompliance', 2006, 208-9.

${ }^{68}$ Thanks to Alice Donald for suggesting this reaction.
} 
considerations, and especially not in the cases considered here: they are not simply claiming to be exceptions to existing norms, but rather improvements of existing norms.

The account has indicated that domestic parliaments can serve important purposes in increasing the credibility of the law breaking as sincere attempts at law making. Such potential should not be overdrawn. Parliamentary debates are also crucial arenas for parties to gather votes by means of 'IC-bashing'. There is no reason to believe that such debates will abide by the deliberative ideals of democratic theorists. ${ }^{69}$

Paradoxically, ICs that seek to promote well-functioning democratic parliamentarian debates - such as the ECtHR - may thereby also engender opportunities for more justified international civil disobedience. The result of such law breaking by national parliaments may indeed in the shorter term be a less stable international legal order, but such means may be one of the few forms of international law making left to states which seek to promote a more legitimate stable international legal order.

${ }^{69}$ C. Hillebrecht, Domestic Politics and International Human Rights Tribunals: The Problem of Compliance (New York: Cambridge University Press, 2014), I owe this reference to Matthew Saul. 